\title{
THE EFFECT OF WORKPLACE SPIRITUALITY DIMENSIONS ON ORGANIZATIONAL COMMITMENT WITH PERCEIVED ORGANIZATIONAL SUPPORT AS A MODERATING VARIABLE
}

\section{Diaz Haryokusumo}

STIE YKPN Yogyakarta, Yogyakarta, Indonesia

\begin{tabular}{l} 
Info Artikel \\
Sejarah Artikel: \\
Diterima Juni 2015 \\
Disetujui Juli 2015 \\
Diterbitkan September 2015 \\
\hline Keywords: \\
Spiritual Dimensions; \\
Organizational Commitment; \\
Perceived Organizational Support
\end{tabular}

\section{PENGARUH DIMENSI SPIRITUALITAS TEMPAT KERJA PADA \\ KOMITMEN ORGANISASIONAL DENGAN DUKUNGAN ORGANISASIONAL PERSEPSIAN SEBAGAI VARIABEL PEMODERASI}

\begin{abstract}
Abstrak
Tujuan dari penelitian ini adalah untuk menguji pengaruh dimensi spiritualitas kerja (kehidupan batin, pekerjaan yang bermakna, dan kondisi masyarakat) terhadap komitmen organisasi (afektif, continuance, dan normatif) dan juga untuk menguji efek moderasi dari dukungan organisasi yang dirasakan. 130 kuesioner dikumpulkan dari enam organisasi di Yogyakarta. Hasil penelitian menunjukkan bahwa dimensi spiritualitas kerja memiliki efek positif pada komitmen afektif. Pengujian efek moderasi menunjukkan bahwa dukungan organisasi yang dirasakan tidak memoderasi efek positif dari dimensi spiritualitas kerja pada komponen komitmen organisasi. Berdasarkan penelitian ini, kondisi masyarakat memiliki efek terbesar pada komitmen afektif, sementara kehidupan batin memiliki efek terbesar pada komitmen normatif dan continuance. Implikasi untuk teori dan praktek manajemen juga dibahas dalam penelitian ini.
\end{abstract}

JEL Classification: M0, M5, M54 


\section{INTRODUCTION}

The workplace spirituality (WS) issue is rapidly growing in academics and organizational practice since the beginning of new millennium (Vasconcelos, 2009; Lazar, 2010). The development of WS according to Ashmos and Duchon (2000) appear due to several causes; 1) moral and ethics degradation of employees, high welfare gap due to rapid downsizing, 2) workplace environment becomes a major source of social activities, due to the decreasing of social interactions in outside environment, 3) interest in Pacific Rim cultures and Eastern cultures, 4) development of the importance of meaning of life at work, 5) the meaning of work is needed to create the creativity and interest in work (head and heart will be a competitive advantage)

Duchon and Plowman (2005) argue WS appears due to the decreasing of traditional context of community (e.g. neighbourhoods, place of pray) which making the employees come to workplace with less of spiritual needs. Duchon and Plowman (2005) explained this makes the access of life meaning fulfilment and togetherness (sense of belonging) increasingly limited. As a result, the workplace has become a place to realize employee's goal of life (Geldenhuys et al., 2014). Compensation theory (Staines, 1980) states that there is a reciprocal relationship between work and life. Employees will do various efforts in trying to pursue something they feel is missing. The employees will look for the spirituality in their workplace when to have no chance to chase it out of work.

Workplace spirituality is recognition of inner life which nourishes and nourished by meaningful work that occurs within a community context (Duchon \& Plowman, 2000). Definition of WS Ashmos and Duchon (2000) has three main components. First, WS means employees are spiritual beings; they have an inner life that indicates the need for a meaning in every activity. Second, WS is not only about the nature of the employees who need meaning, but also a sense of belonging and being part of a community (condition for the community). Third, this variable includes the idea that the employee needs for meaning can be achieved through the meaningful work.

Based on existing empirical research, WS found to have positive effect on employee satisfaction (Milliman et al., 2003; Lazar, 2009; Piryaei \& Zare, 2013), organizational citizenship behavior (Rastgar et al., 2012; Kazemipour et al., 2012), turnover intention (Milliman et al., 2003; Hong, 2012), work involvement (Milliman et al., 2003; Kolodinsky et al., 2008; Pawar, 2009), and reduce the stress at work (Kolodinsky et al., 2008). Another form of positive work attitude that is a consequence and have a positive relationship with WS is an organizational commitment (Jurkiewicz \& Giacalone, 2004). Some empirical research also found positive support between WS and organizational commitment (Milliman et al., 2003; Rego \& Cunha, 2008; Pawar, 2009).

Organizational commitment is an important topic for organizational study (Sudarna, 2014; Fitriastuti, 2013). The model of organizational commitment from Allen and Meyer $(1990,1991)$ is one of the most widely used model in research (Rego \& Cunha, 2008). This model distinguishes commitment into three commitments; affective (emotional attachment to the organization), continuance (cost of investments; that had to be sacrificed when leaving the organization), and normative (sense of duty toward organization). Each component contributes to strengthening the possibility of the employee to remain in the organization.

The result of meta-analysis study by Meyer, Stanley, Hersovitch, and Topolnytsky (2002) shows those three components have a negative relationship with turnover intention and withdrawal cognition. The affective component has negative relationship toward absenteeism, stress, and work-family conflict, and it has positive relationship toward the level of attendance, the performance of employees, and organizational citizenship behavior. 
Diaz Haryokusumo / The Effect of Woekplace Spirituality Dimension...

Both of these variables have an urgency to be researched, but the empirical study still rarely done (Duchon \& Plowman, 2005; Rego \& Cunha, 2008), and thus require additional support of empirical research.

The author predicts that WS dimension has a different effect on each component of organizational commitment. Previous researches (Milliman et al., 2003; Rego \& Cunha 2008) show each dimension of WS has a different effect on the component of organizational commitment. Meyer and Allen (1991) explained that these three components have a different antecedent. Rego and Cunha (2008) add each component that separated by Allen and Meyer contribute in strengthening the possibility of employees to remain in the organization, but the nature of each concept is different. From the limited research that tests the effect of WS to organizational commitment, testing on dimension level on both variables is rarely done. Pawar (2009) and Marschke et al.(2009) use organizational commitment as one-dimensional. Also, research was conducted by Milliman et al. (2003) test the effect of WS only toward the affective commitment. The above explanation brought this research to a multi-dimensional approach.

Milliman et al. (2003) and Rego and Cunha (2008) suggest that the effect of interaction need to be presented in the relationship of WS and organizational commitment. Jurkiewicz and Giacalone (2004) state the number of other variables that can affect the level of organizational commitment make the relationship of WS and consequences variable became much more complex. Therefore, it is important to define and test the moderating variables on that relationship (Jurkiewicz \& Giacalone, 2004). Kolodinsky et al. (2008) argue the organizational factor can influence the effect of WS. This study will examine the role of perceived-organizational support (POS) as a moderating variable. Based on the individual centred perspective from Krishnakumar and Neck (2002), WS can be developed from the perspective of the individual. In this perspective, the organization must seek to accommodate and encourage the spiritual needs of the employee (Cash \& Gray, 2000). To increase WS, Thompson (2000) argues that it should begin with encouraging the individual to declare the spirituality idea and help them through the organizational value.

Rego and Cunha (2008) shows that POS can affect the relationship between WS and commitment. Research from Huang and Lin (2014) confirms the role of POS, which can moderate the relationship between WS and work involvement. The results of this research indicate when employees feel the existence of POS, the employees feel the effort of the organization to provide and facilitate their spiritual side at the workplace. It is not adverse to the organization, because, through social exchange, employees are expected to provide the best effort and decided to remain in the organization because the organization facilitates their needs.

In the middle of rising volume on WS research, research context still dominated by country-specific backgrounds such as the Western backgrounds, South American including the United States, Portugal, Brazil, and a small number of Southeast Asia's country (Petchsawanga \& Duchon, 2009; Mat \& Koh, 2011). It condition makes the empirical evidence in the context of other countries is very limited (Mat \& Koh, 2011). Differences in the context of the country allow that there is a difference of results so that the research needs to be done to see the difference context will give a different result. The author will conduct the research to test workplace spirituality practice in Indonesia.

\section{Theoritical Framework and Hypothesis Development Workplace Spirituality}

Spirituality, when viewed through the existentialist paradigm, emphasizes the idea of the search for meaning in every human activity (Khrishnakumar \& Neck, 2002).The concept of workplace spirituality is different from the 
religion or belief system (Garcia-Zamor, 2003; Laabs, 1995).Spirituality is not a conversion of a particular religious belief or system (Laabs, 1995). Ashmos and Duchon (2000) argues worklace spirituality is not about a person who receives a certain belief system but related to employees who understands himself as a spiritual being whose soul must be presented in the work. Ashmos and Duchon (2000) defines workplace spirituality as the recognition that employees have an inner life that nourishes and nourished by meaningful work that take place in the context of community.

\section{Inner Life}

Inner life dimension refers to people bring their whole selves to work, includes the spiritual self (Duchon \& Plowman, 2005). This dimension contains the notion that employees have spiritual needs (i.e. an inner life), just as they have phsycal, emotional, and cognitive needs, and these needs don't get left at home when they come to work (Duchon \& Plowman, 2005). The inner life, for many, is about coming to understand one's own divine power and how to use that divine power to live a more satisfying and more full outer life (Ashmos \& Duchon, 2000)

\section{Meaningful Work}

The second dimension of workplace spirituality embodies the notion that people seek to mean at works. The notion of meaningful work is about cognitive job that creates sense of joy, which connects workers to a larger good and and to things viewed by workers as important in life (Duchon \& Plowman, 2005). Ashosh and Duchon (2000) explain that after reconizing a spiritual element in employees, the expression of spirituality at work requires accepting that employees want to be involved in work that gives meaning to their lives. Meaningful work cover how the working activity can create joy, enthusiasm, and about the connection between the soul and work (Asmos \& Duchon, 2000).

\section{Condition for Community}

The third dimension of WS from Ashmos and Duchon (2000) relating to the notion that individual as a spiritual being living in a relationship with another individual.The condition for the community includes the notion of sharing, mutual obligations, and commitments that connect one individual to another (Ashmos \& Duchon, 2000; Duchon \& Plowman, 2005). The important dimension that valued by employees in the workplace can feel themselves part of a larger community that can be interconnected, and can build soul and spirit (Pfefer, 2001). This dimension is equal to the theoretical concept of spiritual leadership by Fry (2003), namely membership.

\section{Organizational Commitment}

Organizational commitment can be defined as a psychological state that characterizes an employee's relationship with the organization and reduce the likelihood that he/she will leave it (Allen \&Meyer, 1990). According to Porter et al. (1974) an individual with strong organizational commitment will strive to achieve organization's goal and have a positive view and try to do the best for the benefit of the organization. Morrow (1983) describes the state of a person is committed to the organization if a) believe and accept the goals and values of the organization, b) willing to try to achieve the set objectives of the organization, c) has a strong desire to remain a part of the organization.

\section{Affective Commitment}

Affective commitment is the extent to which a person identifies himself, get involved, and enjoy membership in the organization (Meyer \& Allen, 1991). Employees with a strong affective bond remain because they want to do so. Consequences of affective commitment, which are summarized by Meyer et al. (2002) is the low turnover and extra-role behaviours 
Diaz Haryokusumo / The Effect of Woekplace Spirituality Dimension...

such as organizational citizenship behaviour. Affective commitment develops when the employee becomes involved in, recognize the value-relevance of, and derives his/her identity from the association with the organization (Rego \& Cunha, 2008)

The existence of an inner life seen as an effort to empower individuals to take along their whole self in work, including the spiritual side (Duchon \& Plowman, 2005). The expression of the inner life is a form of employee identity as a spiritual being. Identity is a major source of motivation for an action. When employees can express themselves, it will foster affective commitment (Meyer \& Allen, 1991). According to socioemotional bases of commitment from Burke and Reitzes (1991), the employee will seek to maintain an emotional bond and identity created through interaction with others, in this case, the organization. Based on these descriptions, it can be hypothesized:

H1a: Inner life has a positive effect on affective commitment.

Meaningful work describes the work that has meaning, encouragement, and employees enjoy doing the job (Milliman et al., 2003). Based on Herzberg's theory of motivation, employees who do the work that has meaning will raise job experience that can meet the psychological needs of employees and they are motivated their best effort to work. This kind of work experience according to Meyer and Allen (1991) will be a positive effect on employee's affective commitment. Based on these descriptions, it can be hypothesized:

H1b: Meaningful work has a positive effect on affective commitment.

A study by Milliman et al. (2003) found a positive relationship between the sense of community, which describes the awareness among colleagues, on affective commitment. According to Rego and Cunha (2008) it can be seen with the concept of benevolent activities (e.g. kindness among co-workers) creates positive emotions and trigger a positive attitude of employees towards work and organization. Based on these descriptions, it can be hypothesized:

H1c: The condition for the community has a positive effect on affective commitment.

\section{Contiuance Commitment}

Continuance commitment is one's attachment to the organization based on the amount of the sacrifices made by someone when leaving the organization (Meyer \& Allen, 1991). Continuance commitment reflects employee awareness of the sacrifices and costs as well as loss of investment when leaving the organization (Meyer \& Allen, 1991).This form of investment may be lost benefits gained when it became a member of the organization.

When employees recognize her/hisself has an inner life and become part of a group that accommodates this, the social group then provides an opportunity to express the inner life (Duchon and Plowman, 2005).Employees will decide to stay in the organization to avoid the potential loss of benefits acquired from meaningful work in the workplace. Freedom to express this inner life will then be a positive influence on employee'scontinuance commitment. The hypothesis can be formulated as follows

H2a: inner life has a positive effect on continuance commitment.

Milliman et al. (2003) argue the opportunity to do meaningful work will increase confidence, hope, health, happiness, and selfdevelopment.Employees then decided in the organization to keep its needs remain fulfilled. Meaningful work will be a positive influence on employee'scontinuance commitment. The hypothesis can be formulated as follows:

$\mathrm{H} 2 \mathrm{~b}$ : meaningful work has a positive effect on continuance commitment.

Employees working in a community mustEmployees working in a community must identify themselves as part of a social community to be able to feel the benefits of 
community groups (Duchon and Plowman, 2005). Employees will feel the fellowship effect when they realized they were part of the social community in the workplace. Ashmos and Duchon (2000) suggested the effect of fellowships provide a variety of benefits for employees such as the support of the leadership and co-workers. Lingard and Francis (2006) said that social support has an important role to maintain the well-being of individuals both physically and psychologically. The big ideas to describe the relationship between dimensions of workplace spirituality with normative commitment is Side Bet theory, which states continuance commitment will appear in line with the increase in investment from the employees. Leaving the organization will incur losses, such as loss of community and work colleagues who are seen as a social cost that would arise. The hypothesis can be formulated as follows:

$\mathrm{H} 2 \mathrm{c}$ : The condition for the community has a positive effect to continuance commitment.

\section{Normative Commitment}

Normative commitment is a moral obligation of a person to remain in the organization.Some reasons such as feeling indebted, mutual needs or organizational socialization, employees who have a normative commitment feel they have to stay (Meyer \& Allen, 1991). The feeling of obligation to remain in the organization comes from the the normative pressure to repay all the effort that has been given by the organization (Wiener, 1982). Work experience is believed to be one of the drivers of normative commitment, including other factors such as organizational support, organizational justice, and roles clarity. Normative commitment is positively related to overall job satisfaction and job involvement (Meyer et al., 2002).

In line with the psychological reciprocity concept, when employees feel that the organization provides space to express their inner life, then employees feel obligated to reciprocate the benefits by deciding to remain in the organization. This condition makes the dimensions of the inner lifehas positive effect on employee's normative commitment. The hypothesis can be formulated as follows

H3a: Inner life has a positive effect on normative commitment.

When employees perceive meaningful work, this situation will make employees have a normative commitment (Rego \& Cunha, 2008). Employees who feel the meaning in his work will bring happiness and linking employees to the good things that he considered important in their lives (Duchon \& Plowman, 2005). Normative commitment increases when organizations provide opportunities and space for them. Based on the concept of social exchange, employees will feel have an obligation to reply to efforts made by the organization. The hypothesis can be formulated as follows:

$\mathrm{H} 3 \mathrm{~b}$ : Meaningful work has a positive effect on normative commitment.

Closely related to the previous explanations, support, and acceptance by colleagues, organizations and leaders will make employees feel enjoy staying in the organization. Support and acceptance of employees in the workplace based on the concept of social exchange, employees will feel the responsibility to reply to the treatment he got to the organization. The normative pressure creates a feeling of indebtedness (Wiener, 1982) to be paid by the employee to the organization. It will foster normative commitment and make employees stay in the organization. The hypothesis can be formulated as follows:

$\mathrm{H} 3 \mathrm{c}$ : The condition for the community has a positive effect on normative commitmentf.

\section{Perceived Organizational Support}

Perceived organizational suppport (POS) was defined as the degree to wich employees perceive that the organization cares about their 
Diaz Haryokusumo / The Effect of Woekplace Spirituality Dimension...

well-being and that their contributions are valued by their organization (Eisenberger et al., 1986). According to organizational support theory, POS is encouraged by the tendency of employees to personify an organization as though it were with human-like characteristics.Eisenberger et al. (1986) explain that the POS can enhance the employee's appreciation reward and attention given by the organization to employees.

Employees who perceive the inner life in the workplace will assess their organizations to facilitate and support the realization of this dimension. Employees with a strong perception of organizational support, felt that the organization being fair, provide appreciation and concern for the lives and employee's well-being (Eisenberger et al., 1986). Employees feeling that there is support from the the organization will further strengthen the emotional bond to the organization's employees. Meeting the employee's need for an inner life and appreciation of the contribution of employees will be perceived as organizational support (Eisenberger et al., 1986).

The creation of meaningful work dimension will create happiness when the employee is doing his job (Duchon and Plowman, 2005). Efforts from the the organization to provide employee's well-being is a form of POS (Eisenberger et al., 1986). One of these efforts is to bring happiness to the employees when doing their job.When employees feel the organization facilitates meaningful work for them, then the employees will perceive the organization gave its support to the creation of this dimension.According to Roades and Eisenberger (2002), if the employee considers high organizational support received, the employee decided to become members of the organization and develop a positive perception of the organization.Based on the results of his studies, Milliman et al. (1999) believe that companies that are not only bound by the mind but also the hearts and emotions of its employees will have high profitability. In other words, organizations that sincerely treat employees as part of a working community and emotionally bind them with the goals of the company will gain higher motivation and loyalty from its employees (Milliman et al., 1999). The formulation of hypotheses based on the above explanation is:

H4a:. The positive effect of inner life on affective commitment will be positively moderate by POS. The higher the POS, the higher positive effect on inner life on affective commitment.

$\mathrm{H} 4 \mathrm{~b}$ : The positive effect of meaningful work on affective commitment will be positively moderate by POS. The higher the POS, the higher positive effect of meaningful work on affective commitment.

$\mathrm{H} 4 \mathrm{c}$ : The positive effect of condition for the community on affective commitment will be positively moderate by POS. The higher the POS, the higher positive effect of condition for the community on affective commitment.

Becker (1960, in Meyer \& Allen, 1991) states that continuance commitment arises from the accumulation of "side bet" that would be lost if an activity did not continue. The side bet is created when something important for employees depends on the sustainability of the workand for becoming a member of the organization (Meyer \& Allen, 1991). Based on Ashmos and Duchon (2000), the emergence of inner life, joy in work, and connectedness with the community is very important for employees as spiritual beings.

Various POS activities can be a multiplier effect for benefits perceived by employees gain from the realization of workplace spirituality. Inner life realized when employees can bring their wholeself into the workplace (Ashmos \& Duchon, 2000). It can be reinforced by the organizational support for the strengthening of identity through the process of social identity (Duchon \& Plowman, 2005). The social environment will strengthen the identity of a person through activities in it. Meaningful work will be realized when employees feel the happiness and connect with to things viewed 
by workers as important in life (Duchon and Plowman, 2005). It can be strengthened by the support from the organization through job design and job characteristics that are capable tocreate meaning, responsibility, and understanding the result of the work (Duchon and Plowman, 2005). Connectedness to the community can arise when there is a coworkers support when facing difficult times at work (Ashmos \& Duchon, 2000). Organizations can strengthen this connection with extrarole behavior as stated by George and Brief (1992), such as add colleagues and provide constructive feedback to employees. The hypothesis based on the explanation is:

H5a: The positive effect of inner life on continuance commitment will be positively moderate by POS. The higher the POS, the higher positive effect on inner life on continuance commitment.

H5b: The positive effect of meaningful work on continuance commitment will be positively moderate by POS. The higher the POS, the higher positive effect of meaningful work on continuance commitment.

H5c: The positive effect of condition for the community on continuance commitment will be positively moderate by POS. The higher the POS, the higher positive effect of condition for the community on continuance commitment.

Theforms of organizational support can be an option to spirituality prayer or yoga sessions for employees, or to introduce a program of spiritual health (Krishnakumar \& Neck, 2002; Mitroff \& Denton, 1999). Various studies suggest that support and allowing freedom to express spirituality will make employees feel authentic and complete in the workplace (Burrack, 1999). According to Karakas (2010), it will lead to the employees well-being. Based Rhoades and Eisenberger (2002), employees who believe that organization concern about their well-being, will increase their trust and believe that the organization appreciates their efforts. This trust will generate a sense of obligation to responded by actively participate to increase organizational performance. The emergence of this obligation will be a normative pressure (Wiener, 1982) which then can bring greater normative commitment.

According to Duchon and Plowman (2005) employees who feel meaningful work will have a cognitive task that creates a sense of joy and connected to the good things that are important to them. The meaning of work can arise when organizations make the job design and job characteristics that support it. Burrack (1999) stated that the presence of spirituality will increase the commitment by presenting a climate of trust in the work.Employees who feel the POS will reinforce the belief that the organization cares about them (Rhoades \& Eisenberger, 2002).

Another workplace spirituality form is when employees connect with the community at work (Ashmos \& Duchon, 2000). Connectedness arises when there is fellowship aspect, leaders and co-workers help each others in employees facing difficulties (Ashmos \& Duchon, 2000). Based on George and Brief (1992), extrarole activities performed by the organization can be adding colleagues, protecting the organization and employees from risk and harms, and offer constructive feedback to employees. It implies that employees can feel the support through extrarole efforts of the organization.It makes employees bound and respond by achieving organizational goals (Rhoades \& Eisenberger, 2002). The hypothesis can be formulated from the above explanation is:

H6a: The positive effect of inner life on normative commitment will be positively moderate by POS. The higher the POS, the higher positive effect on inner life on normative commitment.

$\mathrm{H} 6 \mathrm{~b}$ : The positive effect of meaningful work on normative commitment will be positively moderate by POS. The higher the POS, the higher positive effect of meaningful work on normative commitment. 
Diaz Haryokusumo / The Effect of Woekplace Spirituality Dimension...

H6c: The positive effect of condition for the community on normative commitment will be positively moderate by POS. The higher the POS, the higher positive effect of condition for the community on normative commitment.

\section{METHOD}

Respondents were drawn from six different organizations in Yogyakarta. These organizations were a sample from various sectors, including banking, education, health services, and non-governmental organizations. The questionnaire distributed to 175 employees and 139 returned (response rate 79.4\%); 130 questionnaires that can be processed. Sample using purposive sampling method with the criteria of respondents have tenure, at least, two years. According to Robinson et al. (1994), the perception of employees on its obligations to organizational change within a span of two years. Respondents were mostly male $(53.85 \%)$, relatively young $(32.31 \%$ were 25-30 years of age), with the highest education level is bachelor degree (59.23\%). Respondents with tenure for two to five years had the greatest frequency (65 respondents, 50\%).

The measurements used were a questionnaire that has been developed and validated by pre-vious researchers. The original questionnaire in English, and has been translated into Indonesian by the writer. All-multi item scales were measured on a Likert scale ( $1=$ "strongly disagree," 5=" strongly agree").

Dimensions of workplace spirituality were measured using 21-item developed by Ashmos and Duchon (2000), consist of five items for the inner life, seven items for meaningful work, and nine items for a condition for the community. The coefficient alphas were 0.75 (inner life), 0.95 (meaningful work), and 0.89 (condition for the community). Sample items include, "My spiritual values influence the choice I make". Three components of organizational commitment were measured using an 18-item scale developed by Meyer,
Allen and Smith (1993) with six items for each type of commitment. The coefficient alphas were 0.84 (affective), 0.71 (continuance), and 0.80 (normative commitment). Sample items include, "I would be very happy to spend the rest of my career with this organization."

Finally, we used an 8-item version of the scale developed by Eisenberger (1986) to measure perceived organizational support. Its coefficient alpha in this study was .88. Sample items include, "The organization values my contribution to its well-being." In this study, age and tenure comprised as primary control variables. In a meta-analysis conducted by Meyer et al. (2002), this age and tenure are demographic variables that influence positively on all components of organizational commitment.

\section{Social Desirability Bias}

This study applies the design of the study procedure from Podsakoff, MacKenzie, Lee, and Podsakoff (2003) to prevent social desirability bias. This type of bias can cover the relationship between two or more variables (suppressor effect), and can produce improper correlations between independent and dependent variables (spurious effect). First, the guarantee of the confidentiality of information and the results of the questionnaire, as well as the statement that there is no right or wrong answers. Second, this study used reverse-coded items method to reduce the bias of response pattern. Third, the measurement scale mixed without forming a particular grouping (counterbalance question order) to prevent the respondent to guess or infer certain groups of questions to measure certain variables, this effect can lead to bias when answering.

\section{RESULTS AND DISCUSSION}

\section{Validity Test}

We performed Confirmatory Factor Analysis (CFA) with varimax rotation to test the discriminant and convergent validity of 
the instrument. To measure the degree of association between variables and the level of validity, we using the Kaiser-Meyer-Olin Measure of Sampling Adequacy (Kaiser's MSA). Rule of thumb used is the value of the MSA must be greater than 0.5 (Hair et al., 2010).

We previously did face validity by asking the instrument that has been translated to the behavioral science experts. Validity testing conducted in two rounds. KMO value in the second round of the factor analysis was 0.835 and Bartlett's test of significance level was 0.000 . In the second round of factor analysis, all of the items did not show any cross-loading with factor loadings $>0.5$ and clustered in seven components. Therefore, all indicators were valid and can proceed to the next instrument testing.

\section{Descriptive Statistics}

Table 1 shows the means, standard deviations, and correlations among variables in this study. The correlation between dimensions of workplace spirituality and components of organizational commitment ranged from .81 to .61 (all $\mathrm{p}<.05)$; the correlation between dimensions of workplace spirituality and POS ranged from .30 to .56 (all $\mathrm{p}<.05$ ); and the correlation between components of organization commitment and POS ranged from .18 to $.49($ all $\mathrm{p}<.05)$. The average age of respondents was 34.75 years with the average 9.8 years of tenure. Overall, respondents had a high response for each variable. The average value of all variables is above three.

\section{Moderated Regression Analysis}

Main effects workplace spirituality dimensions on affective commitment (Hypothesis1a-1c). The result of these hypothesis testing can be seen in table 2 . Inner life had a significant, positive effect on affective $\operatorname{commitment}(\beta=.503 ; \mathrm{t}=3.586 ; \mathrm{p}<.05)$. Therefore, H1a is supported. Model 3 in table 2 shows that meaningful work had a significant and positive effect on affective commitment $(\beta=.219 ; \mathrm{t}=2.507 ; \mathrm{p}<.05)$. Therefore, $\mathrm{H} 1 \mathrm{~b}$ is supported. Main effect of condition for community to affective commitment on hypothesis $1 \mathrm{c}$ also shows significant and positive result $(\beta=.599 ; \mathrm{t}=6.780 ; \mathrm{p}<.05)$. From this analysis, $\mathrm{H} 1 \mathrm{c}$ is supported.

Main effects workplace spirituality dimensions on continuance commitment (Hypothesis2a-2c). Table 3 presents the result of the regression analysis for $\mathrm{H} 2 \mathrm{a}-\mathrm{c}$. In model 2, inner life had a significant and positive effect on

Table 1. Means, Standard Deviations, and Correlations among Variables ${ }^{\mathrm{a}}$

\begin{tabular}{|c|c|c|c|c|c|c|c|c|c|c|c|c|}
\hline & Variables & Mean & s.d. & 1 & 2 & 3 & 4 & 5 & 6 & 7 & 8 & 9 \\
\hline 1. & Age & 34.75 & 9.97 & & & & & & & & & \\
\hline 2. & Tenure & 9.80 & 9.13 & $.89^{*}$ & & & & & & & & \\
\hline 3. & Inner life & 3.97 & 2.48 & .05 & -.04 & $(.75)$ & & & & & & \\
\hline 4. & Meaningful work & 3.63 & 4.24 & .06 & .00 & $.42 *$ & $(.95)$ & & & & & \\
\hline 5. & Condition for community & 3.77 & 3.89 & .14 & .09 & $.46^{*}$ & $.45^{*}$ & $(.89)$ & & & & \\
\hline 6. & Affective commitment & 3.63 & 4.06 & .09 & .04 & $.32 *$ & $.32 *$ & $.61^{*}$ & $(.84)$ & & & \\
\hline 7. & Continuance commitment & 3.10 & 3.25 & .16 & .09 & $.25^{*}$ & $.26^{*}$ & $.18^{*}$ & $.24 *$ & $(.71)$ & & \\
\hline 8. & Normative commitment & 3.78 & 3.63 & $.27^{*}$ & $.25^{*}$ & $.29 *$ & $.52 *$ & $.34 *$ & $.31 *$ & $.27 *$ & $(.80)$ & \\
\hline 9. & Perceived organizational support & 3.56 & 4.95 & .08 & -.02 & $.30 *$ & $.33^{*}$ & $.56^{*}$ & $.49 *$ & $.18 *$ & $.30 *$ & $(.88)$ \\
\hline
\end{tabular}

Sourche: data processed (2014) 
Diaz Haryokusumo / The Effect of Woekplace Spirituality Dimension...

continuance commitment $(\beta=.294 ; \mathrm{t}=2.585 ; \mathrm{p}$ $<.05)$. Therefore, hypothesis $2 \mathrm{a}$ is supported. In model 3, meaningful work had positive and significant effect on continuance commitment $(\beta=.142 ; \mathrm{t}=1.988 ; \mathrm{p}<.05)$. Based on this analysis, hypothesis $2 \mathrm{~b}$ is supported. Meanwhile, the positive effect of condition for community on continuance commitment in hypothesis $2 \mathrm{c}$ (model 4$)$ is not supported $(\beta=.003 ; \mathrm{t}=.041 ; \mathrm{p}$ $>.05$ ).

Main effects workplace spirituality dimensions on normative commitment (Hypothesis3a-3c). Table 4 shows the test result for hypothesis 3a-3c. As shown in model 2, inner life had significantly positive effect on normative commitment $(\beta=.427 ; t=3.500 ; p<.05)$. Thus, the test has supported hypothesis 3a. Model 3 shows that meaningful work had a significant, positive effect on normative commitment $(\beta=$ $.413 ; \mathrm{t}=6.017 ; \mathrm{p}<.05)$. Therefore, hypothesis $3 \mathrm{~b}$ is supported. On the other hand, hypothesis $3 b$ is not supported $(\beta=.077 ; t=.949 ; p>.05)$, condition for community had positive but not significant effect on normative commitment.

Moderating effects of POS on the relationship between workplace spirituality dimensions and affective commitment
(Hypothesis 4a-4c). Table 2 shows rejection for all hypothesis $4(\mathrm{H} 4 \mathrm{a}-4 \mathrm{c})$. Specifically, a non-significant moderating effects of POS on hypothesis $4 \mathrm{a}(\beta=-.039 ; \mathrm{t}=-1.643 ; \mathrm{p}>.05)$ and hypothesis $4 c(\beta=-.003 ; t=-.276 ; p>.05)$. Unexpectedly, hypothesis $4 \mathrm{~b}$ had significant, but negative effect of moderation ( $\beta=-0.042$; $\mathrm{t}=-3.058 ; \mathrm{p}<.05)$. Based on this analysis, hypothesis $4 \mathrm{a}-4 \mathrm{c}$ is not supported.

Moderating effects of POS on the relationship between workplace spirituality dimensions and continuance commitment (Hypothesis 5a-5c). Moderated regression analysis for hypothesis 5a-5c shown in Table 3. Model 6 shows a non-significant moderating effect of POS on the relationship between inner life and continuance commitment $(\beta=$ $.009 ; \mathrm{t}=.407 ; \mathrm{p}>.05)$. Therefore, Hypothesis $5 \mathrm{a}$ is not supported. For hypothesis $5 \mathrm{~b}$ (model 7 ), regression analysis shows that POS had negative but not significant moderation effect on the relationship between meaningful work and continuance commitment $(\beta=-.015 ; \mathrm{t}=$ -1.802; $\mathrm{p}$ >.05). Accordingly, hypothesis $5 \mathrm{~b}$ is not supported. The same result occured on hypothesis $5 \mathrm{c}$. Model 8 shows that, POS had negative, but not significant moderation

Table 2. Results of Moderated Regression Analysis with Affective Commitment as Dependent Variable

\begin{tabular}{|c|c|c|c|c|c|c|c|c|}
\hline Variables ${ }^{b}$ & Model 1 & Model 2 & Model 3 & Model 4 & Model 5 & Model 6 & Model 7 & Model 8 \\
\hline \multicolumn{9}{|l|}{ Controls } \\
\hline Age & .103 & .051 & .040 & .028 & .004 & .012 & -.014 & -.012 \\
\hline Tenure & -.083 & -.027 & -.018 & -.033 & -.003 & -.012 & .020 & .017 \\
\hline \multicolumn{9}{|l|}{ Main effects } \\
\hline IL & & $.503 *$ & $.349 *$ & .036 & .036 & 1.090 & .082 & .074 \\
\hline MW & & & $.219 *$ & .052 & .035 & .016 & $1.226^{*}$ & $1.200 *$ \\
\hline $\mathrm{CC}$ & & & & $.599 *$ & $.485^{*}$ & $.505^{*}$ & $.465^{*}$ & $.530^{*}$ \\
\hline POS & & & & & $.175^{*}$ & $.962 *$ & $1.160^{*}$ & $1.198^{*}$ \\
\hline \multicolumn{9}{|l|}{ Interactions } \\
\hline IL $x$ POS & & & & & & -.039 & -.002 & -.001 \\
\hline MW x POS & & & & & & & $-.042 *$ & $-.041^{*}$ \\
\hline $\mathrm{CC} \times \mathrm{POS}$ & & & & & & & & -.003 \\
\hline $\mathbf{R}^{2}$ & .014 & $.106^{*}$ & $.148 *$ & $.379 *$ & $.408^{*}$ & .421 & $.463^{*}$ & .463 \\
\hline$\Delta \mathbf{R}^{2}$ & .014 & $.091^{*}$ & $.043 *$ & $.230 *$ & $.030^{*}$ & .013 & $.042 *$ & .000 \\
\hline $\mathbf{F}$ & .926 & $4.962 *$ & $5.449 *$ & $15.122 *$ & $14.153^{*}$ & $12.685^{*}$ & $13.028^{*}$ & $11.499 *$ \\
\hline
\end{tabular}

Sourche: data processed (2014) 
Jurnal Dinamika Manajemen Vol. 6, No. 2, 2015, pp: 187-202

Table 3. Results of Moderated Regression Analysis with Continuance Commitment as Dependent Variable

\begin{tabular}{|c|c|c|c|c|c|c|c|c|}
\hline Variables $^{b}$ & Model 1 & Model 2 & Model 3 & Model 4 & Model 5 & Model 6 & Model 7 & Model 8 \\
\hline \multicolumn{9}{|l|}{ Controls } \\
\hline Age & $.129 *$ & .099 & .091 & .091 & .085 & .083 & .073 & .075 \\
\hline Tenure & -.095 & -.063 & -.057 & -.057 & -.049 & -.047 & -.035 & -.037 \\
\hline \multicolumn{9}{|l|}{ Main effects } \\
\hline IL & & $.294^{*}$ & .194 & .192 & .192 & -.066 & -.430 & -.435 \\
\hline MW & & & $.142 *$ & .141 & .136 & .141 & .578 & .563 \\
\hline $\mathrm{CC}$ & & & & .003 & -.026 & -.031 & -.046 & -.008 \\
\hline POS & & & & & .046 & -.147 & -.075 & -.058 \\
\hline \multicolumn{9}{|l|}{ Interactions } \\
\hline IL x POS & & & & & & .009 & .023 & .023 \\
\hline MW x POS & & & & & & & -.015 & -.015 \\
\hline CC $x$ POS & & & & & & & & -.002 \\
\hline $\mathbf{R}^{2}$ & .038 & $.087^{*}$ & $.115^{*}$ & .115 & .118 & .119 & .128 & .128 \\
\hline$\Delta \mathbf{R}^{2}$ & .038 & $.048^{*}$ & $.028 *$ & .000 & .003 & .001 & .008 & .000 \\
\hline F & 2.541 & $3.997 *$ & $4.056^{*}$ & $3.219^{*}$ & $2.744^{*}$ & $2.359 *$ & $2.214^{*}$ & $1.954 * *$ \\
\hline
\end{tabular}

${ }^{\mathrm{a}} \mathrm{N}=130$. "IN" is "Inner Life", "MW" is "Meaningful Work", "CC" is "Condition for Community", "POS" is "Perceived Organizational Support". ${ }^{*} \mathrm{p} \leq 0,05$

Sourche: data processed (2014)

Tabel 4. Results of Moderated Regression Analysis with Normative Commitment as Dependent Variable

\begin{tabular}{|c|c|c|c|c|c|c|c|c|}
\hline Variables $^{b}$ & Model 1 & Model 2 & Model 3 & Model 4 & Model 5 & Model 6 & Model 7 & Model 8 \\
\hline \multicolumn{9}{|l|}{ Controls } \\
\hline Age & .093 & .049 & .028 & .027 & .013 & .013 & .016 & .024 \\
\hline Tenure & .008 & .055 & .073 & .071 & .087 & .088 & .084 & .075 \\
\hline \multicolumn{9}{|l|}{ Main effects } \\
\hline IL & & $.427 *$ & .136 & .096 & .096 & -.029 & .112 & .085 \\
\hline MW & & & $.413 *$ & $.391 *$ & $.382 *$ & $.384 *$ & .214 & .130 \\
\hline $\mathrm{CC}$ & & & & .077 & .015 & .012 & .018 & .233 \\
\hline POS & & & & & .095 & .002 & -.026 & .073 \\
\hline \multicolumn{9}{|l|}{ Interactions } \\
\hline IL $x$ POS & & & & & & .005 & -001 & .002 \\
\hline MW x POS & & & & & & & .006 & .009 \\
\hline CC $x$ POS & & & & & & & & -.009 \\
\hline $\mathbf{R}^{2}$ & $.075^{*}$ & $.157^{*}$ & $.346^{*}$ & .351 & .362 & .362 & .363 & .368 \\
\hline$\Delta \mathbf{R}^{2}$ & $.075^{*}$ & $.082 *$ & $.189^{*}$ & .005 & .011 & .000 & .001 & .004 \\
\hline $\mathbf{F}$ & $5.146^{*}$ & $7.817 *$ & $16.552 *$ & $13.411^{*}$ & $11.629 *$ & $9.896^{*}$ & $8.626^{*}$ & $7.748^{*}$ \\
\hline
\end{tabular}

$\overline{{ }^{a}} \mathrm{~N}=130$ b" IN" is "Inner Life", "MW" is "Meaningful Work", "CC" is "Condition for Community", "POS" is "Perceived Organizational Support". ${ }^{*} \mathrm{p} \leq 0,05$

Sourche: data processed (2014)

effect on the relation between condition for community and continuance commitment $(\beta=-.002 ; t=-.152 ; \mathrm{p}>.05)$. Consequently, hypothesis $5 \mathrm{c}$ also rejected.

Moderating effects of POS on the relationship between workplace spirituality dimensions and normative commitment
(Hypothesis 6a-6c). Moderated regression analysis for hypothesis $6 a-6 \mathrm{c}$ can be seen in Table 4. Test results of hypothesis 6 a (model 6), POS not significantly moderate the positive effect of inner life on normative commitment $(\beta=.005$; $\mathrm{t}=.207 ; \mathrm{p}>.05)$. The test result for hypothesis $6 \mathrm{~b}$ (model 7), shows that POS not significantly 
Diaz Haryokusumo / The Effect of Woekplace Spirituality Dimension...

moderate the positive effect of meaningful work on normative commitment $(\beta=.006 ; \mathrm{t}=.440$; $\mathrm{p}>.05$ ). Same result for hypothesis $6 \mathrm{c}$ (model 8 ), shos that POS positively, but not significant moderate the positive effect of condition for community on normative commitment $(\beta=$ $.006 ; \mathrm{t}=.440 ; \mathrm{p}>.05)$. Based on the results of this analysis, hypothesis $6 \mathrm{a}, 6 \mathrm{~b}$, and $6 \mathrm{c}$ is not supported.

This study provides several contributions to the literature in the field of workplace spirituality, organizational commitment, and perceived organizational support, especially its application in Indonesia. First, this study shows that all WS dimensions have a positive effect on affective commitment, but it show the different result for continuance and normative commitment. The dimension of condition for the community does not indicate the positive and significant effect on continuance and normative commitment. This case presumably caused by the condition for the community is derived from the social relationship between employees and their community at work. As a result, employees do not feel losing their social investment (side bet) when leaving the organization. In addition, social exchange event tends to occur among individuals in the working community, so it does not trigger the growth of normative commitment toward the organization.

Second, this study showed that the most influential dimensions of WS on affective commitment is a condition of the community. Indonesia, which has a high value of a collective culture that emphasize the social framework and social relationship, thought to be the cause. While, the inner life dimension has the greatest effect on continuance and normative commitment. The dimension of inner life has the greatest average value (mean $=3.97$ ). It is suspected as the main benefits for employees (side bet), thus providing the greatest influence to the continuance and normative commitment.

Third, the result of this study shows perceived organizational support does not indicate a role as a moderating variable in the relationship between workplace spirituality dimensions and components of organizational commitment. We suspect contextual factors greatly influence the outcome of the analysis. For example, high tenure profile of the respondent $($ mean $=9.8)$ foster a high level of self-efficacy that makes employees are very knowledgeable about the nature of their work and how to meet the spiritual needs through the job. Another possible explanation is, in order POS can be received by employees, it must be based on the norm of reciprocity. This norm requires employees to believe in the mutual relationship established with the organization.

The amount of social gap and power distance due to cutural factors of high power distance in Indonesia make the norm of reciprocity between the employee, and the organization is not maximal. The result is, employees will think there is no support from their organization. Hypothesis $4 \mathrm{~b}$ test result even shows POS has negative and significant moderation effect. The emergence of this boomerang effect is presumably due to the inconsistency of organization roles and message received by employees. Organizations can be a source of stress for the task or assignments given, but at the same time also try to provide support. This mixed message could potentially generate negative work attitude on the employees.

\section{CONCLUSION}

This research adds empirical evidence to the multidimensional relationship between the dimensions of workplace spirituality with components of organizational commitment. As far as literature study by the writer, research with a multidimensional approach is only done by Rego and Cunha (2008).In addition, the context of the research taking place in Indonesia is also new findings the effects of WS on work attitudes, particularly organizational commitment. Existing research is still dominated by background world of America or Europe.This study also attempted 
to examine the moderation effects of perceived organizational support in the relationship between workplace spirituality dimensions on organizational commitment.It is also still rarely performed by other researchers to examine the effects of the interaction.

Moderated regression analysis test results from the moderating effects in this study are expected to be a reference for a further study to explore others interactions effect, both mediation and moderation that are still very likely affect workplace spirituality. In addition, we also obtain information about which dimension of workplace spirituality that have a dominant effect in influencing each type of organizational commitment. This research also tries to explore the psychological mechanism that links between workplace spirituality and organizational commitment. As the initial effort, Identity Theory of Burke and Reitzes (1991) proved to be a bridge between the two variables.

The findings suggest that organizational support provide space to actualize spiritual life, not only brings benefits to employees, but also enhance organizational performance. Organizations can start to embed or reinforce the climate of spirituality in the workplace. It can be achieved by various organizational change approach that effectively implement the philosophy of workplace spirituality. The application of this philosophy should accompany with clear prganizational's vision, mission, and values.

Organizations can actively seek the concept and meaning of workplace spirituality in their organizational context by initiating open discussion or open seminar and expecting active participation of all organization's members. The organization's efforts in implementing the climate of spirituality in the workplace will expand the limits of freedom that exist in the organization, given the highly personalized nature of spirituality. That requires a strong commitment from the organization. Training programs such as interpersonal communication training may be required to support the success of implementing workplace spirituality in the organization.
We collected data with a self-report method that can bring out common method bias. The following research can perform a variety of methods to control common method bias such as procedural improvements and statistical methods. Data collection procedure in this study is only done through the survey by distributing questionaires. Future studies could use triangulation methods, for example by using survey and complemented by interviews.

Additional information can be asked to respondent, so richer information can be added to accompany the statistical test. Perceived organizational support as a moderating variable in this study not shown to have a significant effect on the relationship between workplace spirituality dimensions and organizational commitment components. Future studies may be consider involving research contexts such as type or nature of the organization, cultural background of the respondents, or organizational culture in moderating the relationship between workplace spirituality and its concequences.

\section{REFERENCES}

Allen, N. J \& Meyer, J. P. 1990. The Measurement and Antecedents of Affective, Continuance, and Normative Commitment to the Organization. Journal of Occupational Psychology. 63: 1-18.

Ashmos, D. P \& Duchon, D. 2000. Spirituality at Work: A conceptualization and Measures. Journal of Management Inquiry. 9 (2): 134-145.

Burke, P.J \& Reitzes, D. C. 1991. An Identity Theory Approach to Commitment.Social Psychology Theory. 54 (3): 239-251.

Burrack, E. H. 1999. Spirituality at the workplace. Journal of Change Management. 124: 280-291.

Cash, K. C \& Gray, G. R. 2000. A Framework for Accomodating Religion and Spirituality in the Workplace. Academy of the Management Executive. 14 (3): 124-34.

Duchon, D \& Plowman, D. A. 2005. Nurturing the Spirit at Work: Impact on work unit performance. The Leadership Quarterly. 16: 807-833. 
Diaz Haryokusumo /The Effect of Woekplace Spirituality Dimension...

Eisenberger, R., Huntington, R., Hutchison, S \& Sowa, D. 1986. Perceived Organizational Support. Journal of Applied Psychology. 71 (3): 500-507.

Fitriastuti, T. 2013. Pengaruh Kecerdasan Emosional, Komitmen Organisasional Dan Organizational Citizenship Behavior Terhadap Kinerja Karyawan. Jurnal Dinamika Manajemen. 4 (2).

Geldenhuys, M., Laba, K \& Venter, C. M. 2014. Meaningful Work, Work Engagement, and Organizational Commitment. SA Journal of Industrial Psychology. 40 (1): 1-10.

George, J. M \& Brief, A. P. 1992. Feeling gooddoing good: A conceptual analysis of the mood at work-organizational spontaneity relationship. Psychological Bulletin. 112: 310329.

Hair, J. F., Black, W. C., Babin, B. J \& Anderson, R. E. (7th Eds.). 2010. Multivariate Data Analysis. New Jersey: Pearson Education.

Hong, Y. J. 2012. Identifying Spirituality in Workers: A Strategy Retention of Community Mental Health Professionals. Journal of Social Service Research. 38 (2): 1p75-186.

Huang, I. L \& Lin, Y. J. 2014. The Relationship Between Workplace Spirituality and Job Involvement Under Mergers and Acquisitions circumstances: the Moderating Effect of Perceived Organizational Support. Paper. Presented at $17^{\text {th }}$ Conference on Interdisciplinary and Multifungsional Business Management. 494-507.

Jurkiewicz, C. L \& Giacalone, R. A. 2004. A Values Framework the Impact of Workplace Spirituality on Organizational Performance. Journal of Business Ethics. 49 (2): 129-142.

Karakas, F. 2010. Spirituality and Performance in Organizations: a literature review. Journal of Business Ethics. 94 (1): 89-106.

Kazemipour, F., Amin, S. M \& Pourseidi, B. 2012. Relationship between Workplace Spirituality and Organizational Citizenship Behavior among Nurses Through Mediation of Affective Organizational Commitment. Journal of Nursing Scholarship. 44 (3): 302-310.

Khrisnakumar, S \& Neck, C. P. 2002. The "what, "why" and "how" of spirituality in the workplace. Journal of Managerial Psychology. 17 (3): 153-164.
Kolodinsky, R. W., Giacalone, R. A., Jurkiewicz \& Carole, L. 2008. Workplace Values and Outcomes: Exploring Personal, Organizational, and Interactive Workplace Spirituality. Journal of Business Ethics. 81: 465-480.

Laabs, J. J. 1995. Balancing Spirituality and Work. Personnel Journal. 79 (9): 60-69.

Lazar, A. 2010. Spirituality and job satisfaction among female Jewish Israeli hospital nurses. Journal of Advanced Nursing. 662: 334-344.

Marschke, E., Preziosi, R \& Harrington, W. J. 2009. Professionals and Executives Support a Relationship between Organizational Commitment and Spirituality in the Workplace. Paper. Presented at The International Business \& Economics Research (IBER) Conferences, Las Vegas.

Mat Desa, N \& Koh Pin Pin, D. 2011. The workplace spirituality and affective commitment among auditors in big four public accounting firms: Does it matter?. Journal of Global Management. 2 (1): 216-226.

Meyer, J. P \& Allen, N. J. 1991. A Three-Component Conceptualization of Organizational Commitment. Human Resource Management Review. 11: 61-89.

Meyer, J. P., Stanley, D. J., Hersovitch, L \& Topolnytsky, L. 2008. Affective, Continuance, and Normative Commitment to the Organization: A Meta Analysis of Antecedents, Correlates, and Concecuences. Journal of Vocational Behavior. 61: 20-52.

Milliman, J., Andrew J. C \& Ferguson, J. 2003. Workplace spirituality and employee work attitude: An exploratory empirical assessment. Journal of Organizational Change Management. 16: 426-447.

Milliman, J., Ferguson, J., Trickett, D \& Condemi, B. 1999. Spirit and Community at Southwest Airlines: An investigation of a spiritual valuesbased model. Journal of Change Management. 12 (3): 221-233.

Mittrof, I. I \& Denton, E. A. 1999. A Study of Spirituality in the Workplace. Sloan Management Review. Summer: 83-91.

Morrow, P. C. 1983. Concept Redundancy in Organizational Research: The Case of Work Commitment. Academy of Management Review. 8 (3): 486-500. 
Pawar, B. S. 2009. Individual spirituality, workplace spirituality, and work attitudes: An empirical test of direct and indirect interaction effects. Leadership \& Organization Development Journal. 30 (8): 759-777.

Petchsawanga, P \& Duchon, D. 2009. Measuring Workplace Spirituality in an Asian Context. Human Resources Development International. 12 (4).

Piryaei, S \& Zare, R. 2013. Workplace Spirituality and Positive Work Attitudes: The Moderating Role of Individual Spiritulity. Indian Journal of Economics and Development. 1 (4): 91-97

Podsakoff, P. M., MacKenzie, S. B., Lee, J. Y \& Podsakoff, N.P. 2003. Common Method Bias in Behavioral Research: A Critical Review of the Literature and Recommended Remedies. Journal Of Applied Psychology. 88 (5)

Porter, L. W., Steers, R. M \& Mowday, R. T. 1974. Organizational Commitment, Job Satisfaction, and Turnover Among Psychiatric Technicians. Journal of Applied Psychology. 59 (5): 603-609.

Rastgar, A. A., Zarei, A., Davoudi, S. M. M \& Fartash, K. 2012. The link between workplace spirituality, organizational citizenship behaviour and job performance in Iran. Arth Prabhand: A Journal of Economics and Management. 1 (6): 52-67.
Rego, A \& Cunha, M. P. 2008. Workplace spirituality and organizational commitment: an empirical study. Journal of Organizational Change Management. 21 (1): 53-75.

Rhoades, L \& Eisenberger, R. 2001. Perceived Organizational Support: A Review of the Literature. Journal of Applied Psychology. 87 (4): 825-836.

Staines, G. L. 1980. Spillover Versus Compensation: A Review of the Literature on the Relationship Between Work and Nonwork. Human Relations. 33 (2): 111-129.

Sudarma, K. 2014. Implementasi Dual Identity Anggota Koperasi Sebagai Wujud Komitmen Organisasional. Jurnal Dinamika Manajemen. $5(1)$.

Thompson, W. D. 2000. Can you train people to be spiritual?. Training and Development. 54 (12): 18-19.

Vasconcelos, A. F. 2009. Spiritual Development in Organizations: A Religious-based Approach. Journal of Business Ethics. 93: 607-622.

Wiener, Y. 1982. Commitment in Organization: A Normative Review. Academy of Management Review. 7 (3): 418-428.

Zamor, G \& Claude, J. 2003. Workplace Spirituality and Organizational Performance. Public Administration Review. 63 (3): 355-363 